\title{
INFLUENCE OF METEOROLOGICAL PARAMETERS ON THE OPERATION OF A GRID - CONNECTED PV SOLAR PLANT
}

\author{
DRAGANA D. MILOSAVLJEVIĆ ${ }^{1^{*}}$ \\ ${ }^{1}$ Faculty of Science and Mathematics, University of Niš, Niš, Serbia
}

\begin{abstract}
Elementary description and information on a grid-connected photovoltaic solar power plant (PV plant) of $2 \mathrm{~kW}$ installed in Niš and the influence of meteorological parameters on its operation are given in this paper. Besides, experimental results of the calculation of the energy efficiency, electrical energy generated and output power of this PV plant operating in the real climate conditions in 2017 are presented. The results regarding climate parameters and characteristic performance parameter of $2 \mathrm{~kW}_{\mathrm{p}}$ PV plant in Niš in 2017 are discussed and it was found that in 2017 annual energy efficiency of this PV plant was $10.63 \%$ and it decreased with the ambient temperature increasing.
\end{abstract}

Keywords: Solar radiation, Photovoltaic conversion, Photovoltaic solar power plant, Energy efficiency, Ambient temperature.

\section{INTRODUCTION}

Right from the beginning the solar power, especially photovoltaic (PV), presents one of the most dominant renewable energy in the world. Solar energy, in particular, photovoltaic (PV) arrays, can fulfill all the electricity needs of mankind. PV systems have been used to supply electrical energy to the millions of people that do not have access to networks (Tobnaghi $\&$ Vafaei, 2016). Electric power supply to remoter households or villages is substantially application of PVs for many incoming years. Over the past two decades, installed off-grid and/or ongrid PV systems have shown their great potential (Pavlović et al., 2013). Number of installed PV systems has rapidly increased. Over recent years worlwide investment in the research of the PV conversion of solar radiation into electricity aiming at the production of high quality, cheap solar modules and other PV systems components has been increasing. Worldwide more and more companies, research and development centers and organizations are competing in research, promotion and production of the PV systems (Pavlović et al., 2015). Up to date worldwide several thousonds of PV systems power of $1 \mathrm{~kW}$ to several hunderds of megawatts have been installed. The performance and operation of a PV system are dependent upon many site-specific factors such as geographical position, season, cloudiness, air pollution and especially ambient temperature (Shravanth et al., 2016). In this study the operation of a gridconnected PV plant installed at the Faculty of Science and Mathematics (FSM) in Niš, Republic of Serbia, were investigated, in particular with respect to the temperature effect. The findings of this study are expected to be useful information for energy yield prediction and loss analysis of the PV systems, especially in moderate continental climate regions.

\footnotetext{
* Corresponding author: dragana82nis@yahoo.com PHYSICS
}

\section{PHOTOVOLTAIC SOLAR POWER PLANT IN NIŠ}

In October, 2012 on the roof of the FSM in Niš a gridconnected PV plant power of $2 \mathrm{~kW}_{\mathrm{p}}$, was installed (Fig.1). The main components of this plant are solar modules, inverter, DC and AC distribution boxes and network connector. This PV plant consists of 10 solar modules made of monocrystaline silicon, single power of $200 \mathrm{~W}$. Solar modules are fixed on the metal bracket, inclined at $32^{\circ}$ towards the South, mounted on the roof of the Faculty and serial interconnected in a string. By appropriate conductors solar modules are connected to DC distribution box, single phase inverter power of $2 \mathrm{~kW}, \mathrm{AC}$ distribution box and the city electrical network. At the output of AC distribution box there is AC voltage $230 \mathrm{~V}, 50 \mathrm{~Hz}$ (Milosavljević et al., 2015).

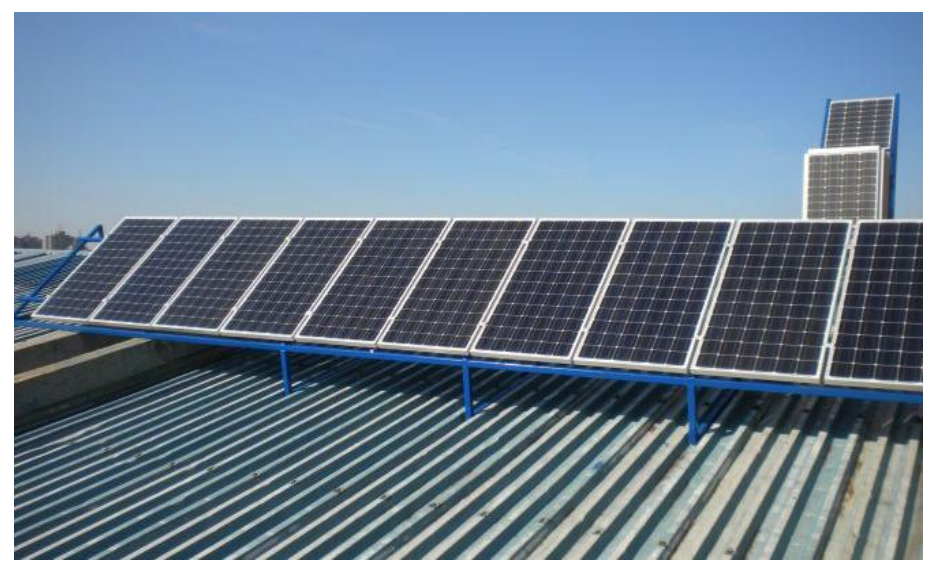

Figure 1. Solar modules inclined at $32^{\circ}$ towards the South on the roof of the building in Niš.

For the remote diagnostics, monitoring and data aquisition of this PV plant, as central communication interface, Sunny WEBBox is used which is by Bluetooth-connected to the inverter 
and by sensor Sunny SensorBox oriented towards the South and tilted at the angle of $32^{\circ}$ on the roof of the building.

Data on PV plant are each 5 minutes recorded in WEBBox where their acquisition is performed. This device enables continuous recording of the electrical parameters of PV plant into the internal memory. Additionally, numeric amounts of the electrical parameters of PV plant are directly recorded on $S D$ memory card or by FTP server (Milosavljević et al., 2015; Milosavljević et al., 2016).

Inverter and additional equipment for the functioning and monitoring of PV plant are placed in the Solar Energy Laboratory, inside the Faculty (Fig.2).

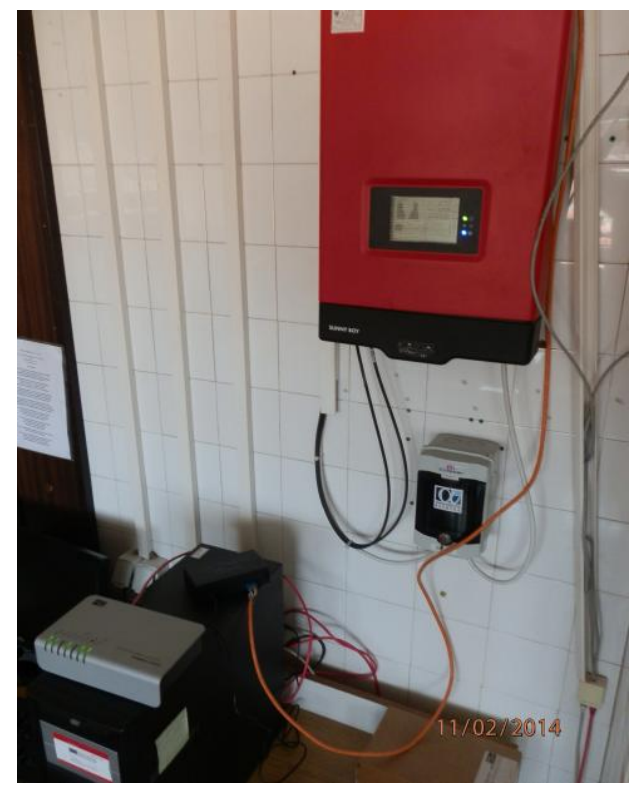

Figure 2. Part of the PV plant inside the Laboratory.

The solar radiation intensity, solar energy, wind speed and the ambient temperature in Niš were measured by Sunny SensorBox. The Sunny SensorBox is connected with Sunny WEBBox through SMA Power Injector with Bluetooth. In combination with Sunny WebBox, it provides a continuous target-actual comparison of system performance (Milosavljević et al., 2015; Milosavljević et al., 2016).

\section{EXPERIMENT}

Variations in the climate, ambient temperature and solar irradiation from month-to-month affect on the performance parameters and operation of PV plant. Therefore, it is very substantially to define which characteristic performance parameters are suitable for which system evaluations based on their weather and climate dependence (Pantić et al., 2016). One of the major causes for the decreased performance of modules is overheating. The efficiency of a solar cell declines by about $0.5 \%$ for every 1 degree Celsius increase in temperature. The most important parameter considered for the performance evaluation of the PV solar plant is the photovoltaic effective conversion efficiency in operative conditions, which affects the electrical energy generation and thus the most valuable product of the component (Hamrouni et al., 2008).

The conversion efficiency of a photovoltaic solar cell or modul is the percentage of the solar energy exposing on a PV system that is converted into usable electricity. Energy efficiency of PV plant indicates a ratio of the electricity generated by PV plant at certain point of time and the solar energy falling on the solar modules at the same point of time (Milosavljević et al. 2015; Milosavljević et al., 2016).

Monthly energy efficiency of PV plant is calculated by means of the Eq. (1) (Chioncel et al., 2010; Attari. et al., 2016; https://www.nrel.gov/docs/fy05osti/37358.pdf;http://www.irena. org/DocumentDownloads/events/2013/March/Palau/4_System_ Design_Guidelines.pdf):

$$
\eta_{M}=\frac{\sum_{i=1}^{n}\left(E_{D}\right)_{i}}{S \cdot \sum_{i=1}^{n}\left(G_{o p t}\right)_{i}}
$$

where $n-$ is a number of days in a month, $E_{D}-$ is a total amount of electricity generated by PV plant and transmitted to the network grid during the day (Wh), $G_{o p t}-$ is a total amount of energy of the global solar irradiation falling during the day on square meter of solar modules of PV plant $\left(\mathrm{Wh} / \mathrm{m}^{2}\right)$ and $S-$ is a total solar modules surface (PV array area) $\left(\mathrm{m}^{2}\right)$.

This experiment was performed in the Solar Energy Laboratory at the FSM in Nis. Experimental energy efficiency of PV plant is calculated by entering into the Eq. (1) measurement data of the daily amount of electrical energy produced by PV plant and measurement data of solar energy falling during the day on PV array area.

\section{RESULTS AND DISCUSSION}

In this section the experimental measurement data of meteorological parameters and some characteristic performance parameter of the $2 \mathrm{~kW}_{\mathrm{p}} \mathrm{PV}$ plant at FSM in Niš for the measured period from January 1, 2017 to January 1, 2018 are analyzed and discussed.

The change of the energy of solar radiation $\left(G_{o p t}\right)$ falling on a square meter of the surface oriented southward, at the angle of $32^{\circ}$ in relation to the horizontal surface, is presented in Figure 3.

Figure 3. shows that in 2017 montly values of the energy of solar radiation $\left(G_{\text {opt }}\right)$ falling on square meter of the surface inclined at $32^{\circ}$ towards the South range from $35,67 \mathrm{kWh} / \mathrm{m}^{2}$ (in December) to $198,33 \mathrm{kWh} / \mathrm{m}^{2}$ (in August). It should be noted that from 20 to 27 May 2017, the device did not register solar radiation so that there were no measurements for that period.

The change of the average monthly values of ambient temperature $T_{a m b}\left({ }^{\circ} \mathrm{C}\right)$ and wind speed $v(\mathrm{~m} / \mathrm{s})$, measured in Niš, in 2017 are presented in Figures 4 and 5, respectively. 


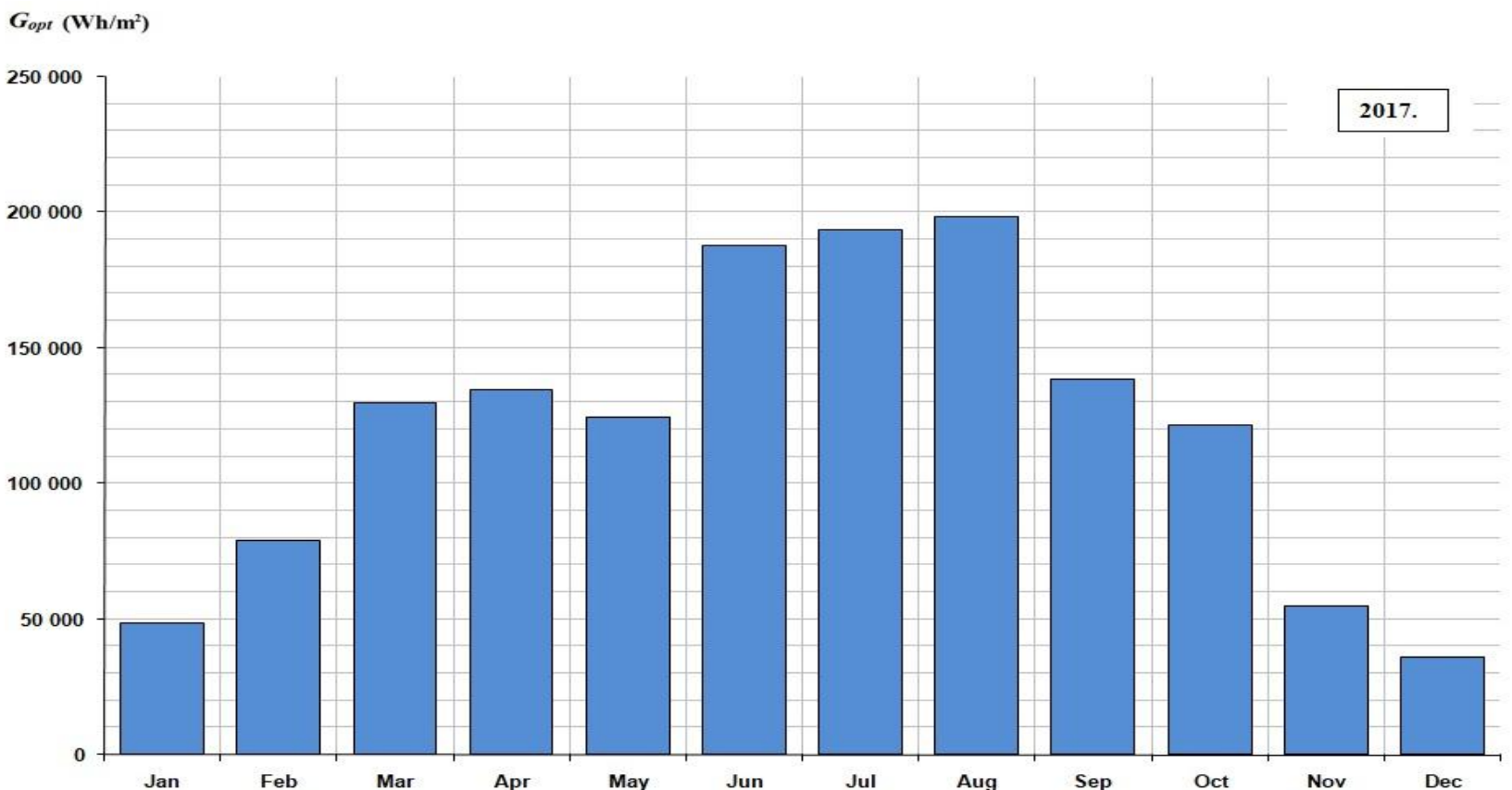

Figure 3. The change of the energy of solar radiation $\left(G_{\text {opt }}\right)$ falling on a square meter of the surface oriented southward, at the angle of $32^{\circ}$ in relation to the horizontal surface.

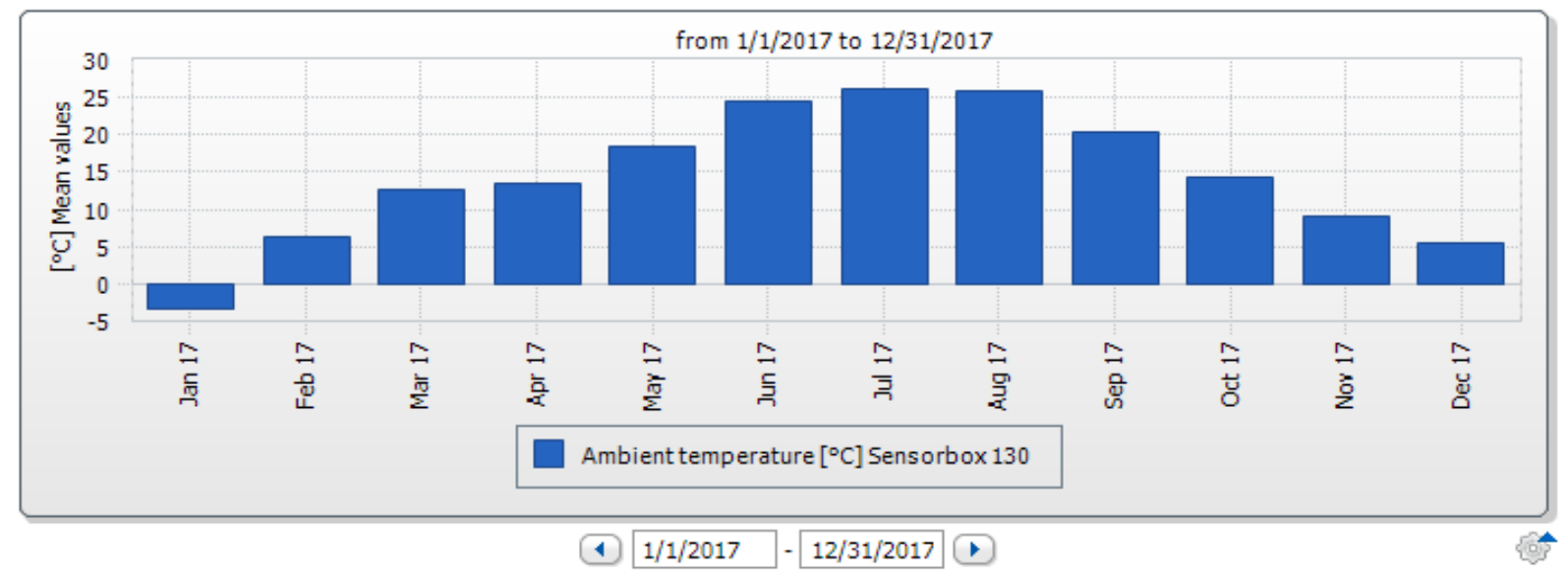

Figure 4. The change of the average monthly values of ambient temperature $T_{a m b}\left({ }^{\circ} \mathrm{C}\right)$, measured in Niš, in 2017.

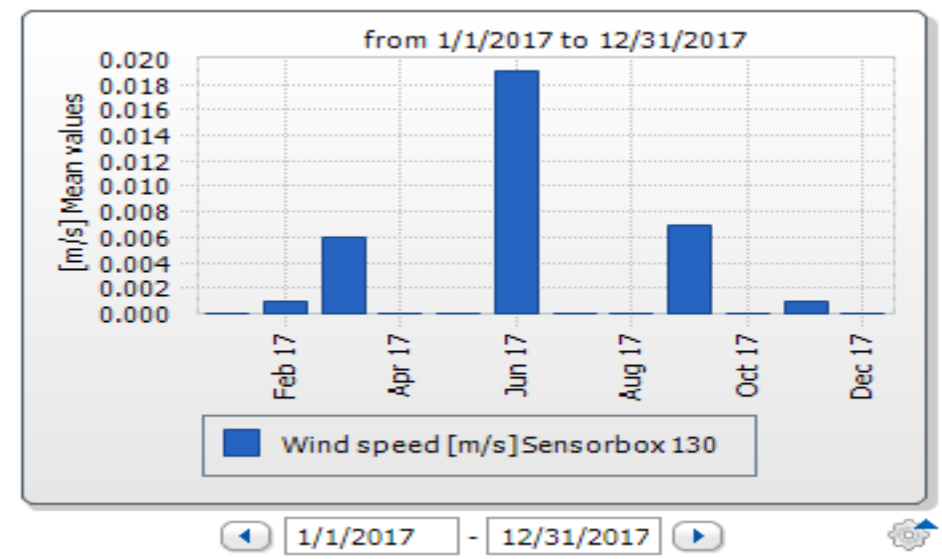

Figure 5. The change of the average monthly values of wind speed $v(\mathrm{~m} / \mathrm{s})$, measured in Niš, in 2017. 


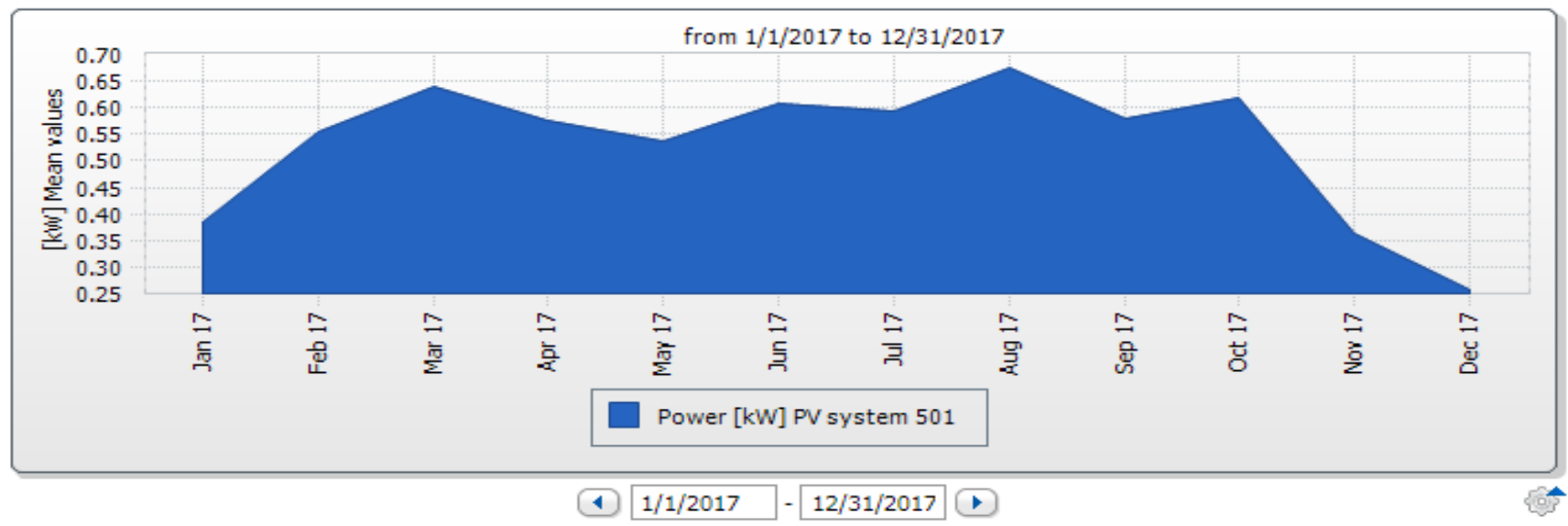

Figure 6. The change of the mean values of output power of PV solar plant of $2 \mathrm{~kW}_{\mathrm{p}}$.

In 2017 average montly values of the ambient temperature $T_{a m b}$ varied from the lowest value of $-3.358^{\circ} \mathrm{C}$ in January to the highest value of $26.076^{\circ} \mathrm{C}$ in July. The average anual value of the ambient temperature is $14^{\circ} \mathrm{C}$. In the same period average montly values of the wind speed $v$ range from $0.00 \mathrm{~m} / \mathrm{s}$ to $0.019 \mathrm{~m} / \mathrm{s}$.

The change of the mean values of output power of PV solar plant of $2 \mathrm{~kW}_{\mathrm{p}}$ is presented in Figure 6.

Figure 6. shows that in 2017 average montly values of the output power of $\mathrm{PV}$ plant of $2 \mathrm{~kW}_{\mathrm{p}}$, varied from $0.258 \mathrm{~kW}$ (in December) to $0.675 \mathrm{~kW}$ (in August). The output power of solar modules strongly depends on solar irradiation falling upon their PV array area (Ayompe et al., 2011).

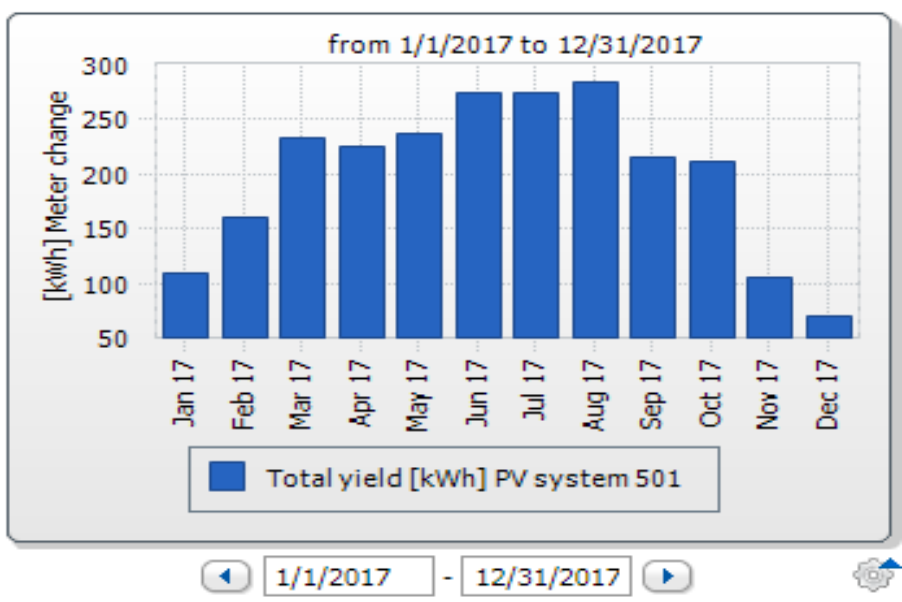

Figure 7. Total monthly amount of the electrical energy produced by PV plant of $2 \mathrm{~kW}_{\mathrm{p}}$ in 2017.

Total monthly amount of the electrical energy produced by PV plant of $2 \mathrm{~kW}_{\mathrm{p}}$ in 2017 is shown in Figure 7.

Figure 7. shows that the total monthly amounts of the electrical energy produced by PV plant of $2 \mathrm{~kW}_{\mathrm{p}}$ in 2017 varied from $69.415 \mathrm{kWh}$ to $284.994 \mathrm{kWh}$.

Graphics of the changes in the experimental values for the total monthly amount of the electricity produced by PV plant $(E)$ depending on the measured montly values of the solar energy
$\left(G_{\text {opt }}\right)$ received by PV array area during the 2017 , is presented in Figure 8.

The major changed by temperature was output voltage which reduces with the increased solar module temperatures. Decrease in output voltage affects the output power of solar module can not be generated effectively even there has increases of the output current. Furthermore, the efficient operation of solar modules and therefore PV plant also decreases with the increasing of solar module temperatures (Shiva \& Sudhakar, 2015; Jahn \& Nasse, 2004; Eltawil \& Zhao, 2010).

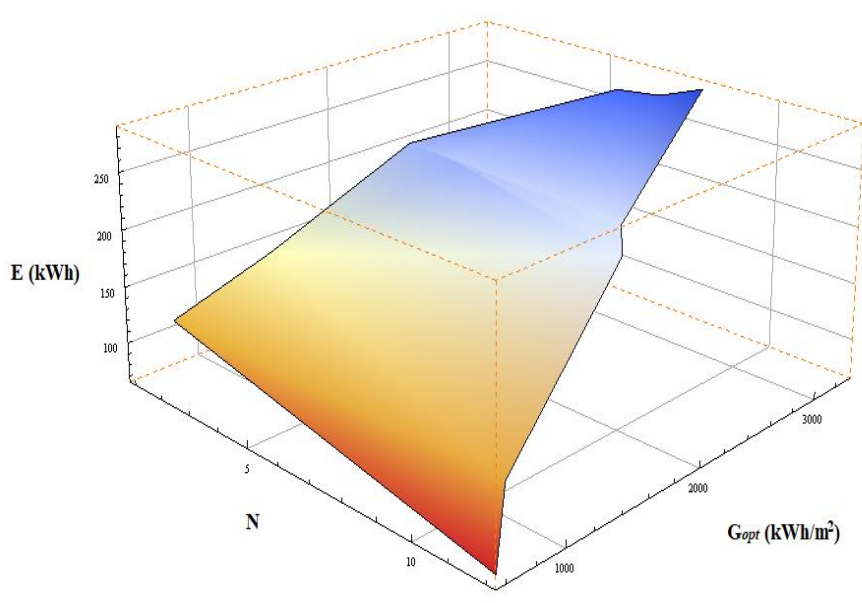

Figure 8. Graphics of the changes in the experimental values for the total monthly amount of the electricity produced by PV plant $(E)$ depending on the measured montly values of the solar energy $\left(G_{\text {opt }}\right)$ received by PV array area during the 2017 ( $\mathrm{N}$ is a number of the month in the year).

Graphics of the change of the monthly energy efficiency $\left(\eta_{M}\right)$ of PV solar plant of $2 \mathrm{~kW}_{\mathrm{p}}$ during the measured period is presented in Figure 9.

Figure 9. shows that the experimentally determined monthly values of the energy efficiency $\left(\eta_{M}\right)$ of PV plant varied from $8.53 \%$ (in July) to $13.74 \%$ (in January), in 2017. The temperature of solar module is increased with increase in solar 
radiation level, as it starts increase above its rated temperature the efficiency goes on reducing. Consequently, the energy efficiency of PV plant is the lowest in the summer months.

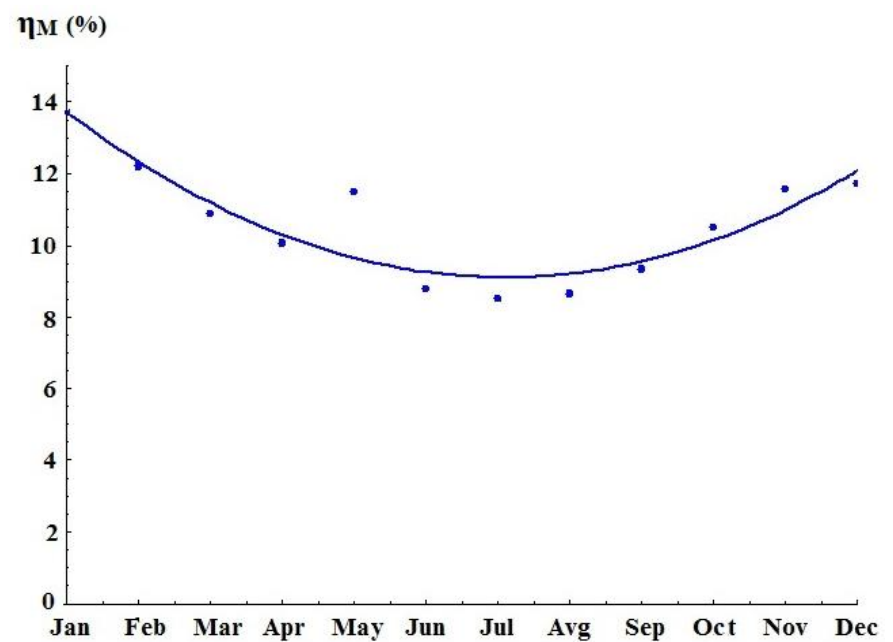

Figure 9. Graphics of the change of the monthly energy efficiency $\left(\eta_{M}\right)$ of PV solar plant of $2 \mathrm{~kW}_{\mathrm{p}}$ during the measured period.

Graphics of the monthly energy efficiency $\left(\eta_{M}\right)$ of PV plant depending on the measured ambient temperature $\left(T_{a m b}\right)$, in 2017 , is given in Figure 10.

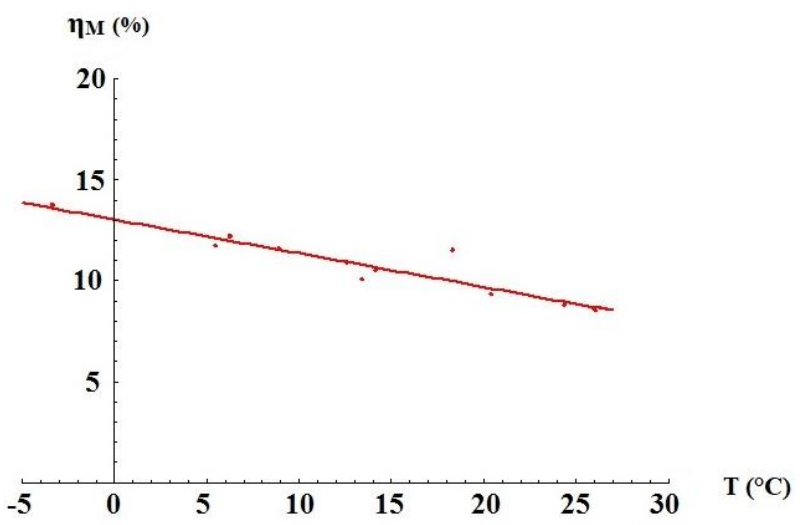

Figure 10. Graphics of the monthly energy efficiency $\left(\eta_{M}\right)$ of PV plant depending on the measured ambient temperature $\left(T_{a m b}\right)$, in 2017.

Energy efficiency of PV plant linearly decreases with increasing the ambient temperature, as shown in Figure 10 Dependence of the energy efficiency of PV plant on the ambient temperature was obtained by a simple linear regression, based on the method of least squares. In this case, the characteristic regression equation is:

$$
\eta_{M}=13.0347-0.166909 T_{a m b}
$$

where $\eta_{M}$ - is the experimental energy efficiency of PV plant and $T_{a m b}$ - is the ambient temperature for the territory of the town of Niš obtained by continuous measurements.
In the Eq. (2) regression coefficient -0.166909 represents slope in a regression model and it responds to the monthl average change of the expected value of dependent variable $\eta_{M}$ for the unit change of the independent variable $T_{a m b}$. Based on the data presented in Figure 10. one can notice that energy efficiency decreases by $0.17 \%$ with the increase in the ambient temperature for $1^{\circ} \mathrm{C}$.

Graphics of the changes in the experimental values for the energy efficiency $\left(\eta_{M}\right)$ of PV plant depending on the measured values of the ambient temperature $\left(T_{a m b}\right)$, and solar energy $\left(G_{o p t}\right)$ received by its PV array area, is given in Figure 11.

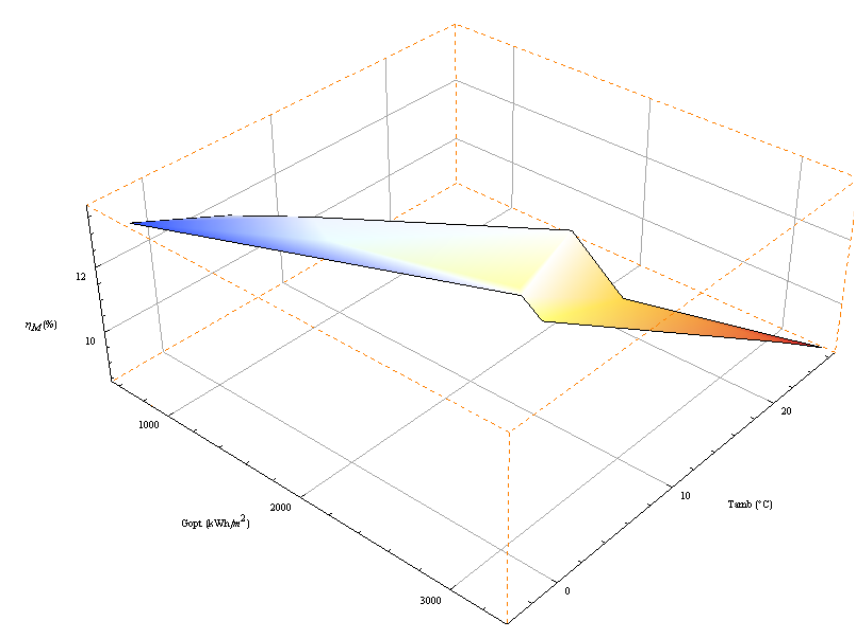

Figure 11. Graphics of the changes in the experimental values for the energy efficiency $\left(\eta_{M}\right)$ of PV plant depending on the measured values of the ambient temperature $\left(T_{a m b}\right)$, and solar energy $\left(G_{o p t}\right)$ received by its PV array area

The ambient and solar module temperature potential are conditioned by the solar radiation. High solar radiation induces the high ambient temperature. The solar module temperature increasing was due to higher insolation heating, low wind speed with the consequent low heat transferred from the module to the ambient. Accordingly, the energy efficiency $\left(\eta_{M}\right)$ of PV plant of $2 \mathrm{~kW}_{\mathrm{p}}$ decreased with the ambient temperature increasing, as can be seen in Figure 11.

\section{CONCLUSION}

Based on the presented results for the measured period from January 1, 2017 to January 1, 2018 it can be concluded that variations in climate, solar radiation and ambient temperature influence on the performance parameters and PV plant operating. The total energy of solar radiation reaching a square meter of the plane oriented southward, at the angle of $32^{\circ}$ in relation to the horizontal plane, for the whole measuremet period, was $1445,189 \mathrm{kWh} / \mathrm{m}^{2}$ and $\mathrm{PV}$ plant has received of 23975.76 $\mathrm{kWh} / \mathrm{m}^{2}$ of solar radiation. PV plant of $2 \mathrm{~kW}_{\mathrm{p}}$ has generated $2400.01 \mathrm{kWh}$ of electrical energy and its annual energy efficiency was $10.63 \%$. 
The ambient temperature is a very important factor in terms of solar module temperature. As the solar irradiation increased, temperature of solar module has also increased which is directly effect to solar module and therefore PV plant electrical efficiency to decrease. The ambient temperature increasing affects on the increasing of thermal vibration of cristal lattice atom of materials used to produce solar cells, which in turn impedes directed movement of free carriers of charging resultin in open circuit voltage decrease and solar cells power degradation. In this case, energy efficiency of PV plant of $2 \mathrm{~kW}_{\mathrm{p}}$ in Niš decreases by $0.17 \%$ for each $1{ }^{\circ} \mathrm{C}$ increase in the ambient temperature.

\section{ACKNOWLEGMENTS}

This study was carried out in the framework of the project TR 33009 approved by the Ministry of Education and Science of the Republic of Serbia.

\section{REFERENCES}

Attari, K., Elyaakoubi, A., \& Asselman, A. 2016. Performance analysis and investigation of a grid-connected photovoltaic installation in Morocco. Energy Reports, 2, pp. 261-266. doi:10.1016/j.egyr.2016.10.004

Ayompe, L.M., Duffy, A., McCormack, S.J., \& Conlon, M. 2011. Measured performance of a $1.72 \mathrm{~kW}$ rooftop grid connected photovoltaic system in Ireland. Energy Conversion and Management, 52(2), pp. 816-825. doi:10.1016/j.enconman.2010.08.007

Chioncel, C.P., \& et al., 2010. Yield factors of a photovoltaic plant. Acta Technica Corviniensis - Bulletin of Engineering, . pp. 63-66.

Eltawil, M.A., \& Zhao, Z. 2010. Grid-connected photovoltaic power systems: Technical and potential problems: A review. Renewable and Sustainable Energy Reviews, 14(1), pp. 112-129. doi:10.1016/j.rser.2009.07.015

Hamrouni, N., Jraidi, M., \& Chérif, A. 2008. Solar radiation and ambient temperature effects on the performances of a PV pumping system. Revue des Energies Renouvelables, . 11 (1), pp. $95-106$.

Retrieved from: https://www.nrel.gov/docs/fy05osti/37358.pdf.
Retrieved from: http://www.irena.org/DocumentDownloads/events/2013/Mar ch/Palau/4_System_Design_Guidelines.pdf.

Jahn, U., \& Nasse, W. 2004. Operational performance of gridconnected PV systems on buildings in Germany. Progress in Photovoltaics: Research and Applications, 12(6), pp. 441448. doi:10.1002/pip.550

Milosavljević, D.D., Pavlović, T.M., \& Piršl, D.S. 2015. Performance analysis of A grid-connected solar PV plant in Niš, Republic of Serbia. Renewable and Sustainable Energy Reviews, 44, pp. 423-435. doi:10.1016/j.rser.2014.12.031

Milosavljević, D.D., Pavlović, T.M., Mirjanić, D.L., \& Divnić, D. 2016. Photovoltaic solar plants in the Republic of Srpska current state and perspectives. Renewable and Sustainable Energy Reviews, 62, pp. 546-560. doi:10.1016/j.rser.2016.04.077

Pantic, L.S., Pavlović, T.M., Milosavljević, D.D., Radonjic, I.S., Radovic, M.K., \& Sazhko, G. 2016. The assessment of different models to predict solar module temperature, output power and efficiency for Nis, Serbia. Energy, 109, pp. 38-48. doi:10.1016/j.energy.2016.04.090

Pavlović, T.M., Tripanagnostopoulos, Y., Mirjanić, D.L., \& Milosavljević, D.D. 2015. Solar Energy in Serbia, Greece and the Republic of Srpska. In Monographs.Banja Luka: Academy of Sciences and Arts of the Republic of Srpska Department of Natural-mathematical and Technical Sciences. Vol. XXVI, Vol. 26, ISBN:978-99938-21-70-0.

Pavlović, T., Milosavljević, D., Radonjić, I., Pantić, L., Radivojević, A., \& Pavlović, M. 2013. Possibility of electricity generation using PV solar plants in Serbia. Renewable and Sustainable Energy Reviews, 20, pp. 201-218. doi:10.1016/j.rser.2012.11.070

Shiva, K.B., \& Sudhakar, K. 2015. Performance evaluation of $10 \mathrm{MW}$ grid connected solar photovoltaic power plant in India. Energy Reports, 1, pp. 184-192. doi:10.1016/j.egyr.2015.10.001

Shravanth, V.M., Srinivasan, J., \& Ramasesha, S.K. 2016. Performance of solar photovoltaic installations: Effect of seasonal variations. Solar Energy, 131, pp. 39-46. doi:10.1016/j.solener.2016.02.013

Tobnaghi, D.M., \& Vafaei, R. 2016. The impacts of gridconnected photovoltaic system on distribution networks - A review. ARPN Journal of Engineering and Applied Sciences, 11 (5), pp. 3564-3570. 